\title{
Effectiveness Of Investigations According To Act No. 23 Of 2004 On Domestic Violence Cases
}

\author{
Aryani Nur Chamidah*) and Ira Alia Maerani**) \\ *)Grobogan Resort Police, E-mail: aryanipurwodadi801@gmail.com \\ **) Faculty of Law Universitas Islam Sultan Agung
}

\begin{abstract}
This study aims to analyze more deeply the investigation of cases of Domestic Violence that occurred in Grobogan which until now has not been effective. The approach used is sociological juridical. Based on the analysis of the existing data, it was found that the implementation of the investigation in the case of Domestic Violence in Grobogan in its development could not be said to be effective. This is because there are still many families or households who do not know that domestic violence is no longer a family matter but has become a public matter, even a violation of human rights and threatens human life. Besides, there are still many law enforcement officers who are not familiar with the Domestic Violence Law. So that there are obstacles for the process of investigating domestic violence cases when victims report to the RPK (Special Service Room) located at the Regional Police Sergeant in each province in Indonesia. Many investigators have not yet carried out the legal service process for victims by carrying out protective procedures specifically stipulated by Act No. 23 of 2004. This has caused victims to withdraw or withdraw their reports and complaints. The legal facilities provided by the Protection Unit have not been implemented properly.
\end{abstract}

Keywords: Effectiveness; Domestic Violence; Investigation.

\section{Introduction}

The wholeness and harmony of a happy, safe, peaceful, and peaceful household is the dream of everyone in the household. To realize this wholeness and harmony, it really depends on everyone in the household, especially the level of quality of behavior and self-control of everyone in the household. Integrity and harmony in the household can be disrupted if the quality of self-control cannot be controlled, which in the end can lead to domestic violence, resulting in injustice to different people within the household. To prevent, protect victims, and take action against perpetrators of domestic violence, the state and society are obliged to carry out prevention ${ }^{1}$. In addition, the state is of the view that all forms of violence, especially domestic violence, are violations of human rights and crimes against human dignity and are forms of discrimination (see General Elucidation of Act No. 23 of 2004 on the Elimination of Domestic Violence). In the Elucidation of Article 3 letter b of Act No.23 of 2004 concerning the Elimination of Domestic Violence it is stated that: What is meant by "gender equality" is a condition where women and men enjoy equal status and have the same conditions to realize in full proportion

\footnotetext{
${ }^{1}$ Ira Alia Maerani, Implementasi Ide Keseimbangan Dalam Pembangunan Hukum Pidana Indonesia Berbasis Nilai-Nilai Pancasila, Jurnal Pembaharuan Hukum Volume II No. 2 May - August 2015, p. 330-331.
} 
to their human rights and potential for the integrity and continuity of the household.

The birth of this law is expected to provide a strong legal basis for the protection of witnesses and victims in providing information that actually occurs to obtain the true truth without experiencing threats or torture as well as possible legal demands for witnesses and victims to report investigations of criminal acts in Indonesia use the Criminal Procedure Code (KUHAP), namely Act No. 8 of 1981, where in the investigation and investigation stage as well as the examination stage in court must be guided by Act No. 23 of 2004 which has given rights and protection of victim witnesses. If necessary, victim witnesses must obtain protection from the Witness and Victim Protection Agency based on Act No. 13 of 2006.

The National Police of the Republic of Indonesia, is one of the government institutions that serves as the spearhead of law enforcement in Indonesia. This task is not easy because it will deal with the community. Law enforcement, not only must the community be aware of the law and obey the law, but it is more meaningful in implementing the law as it should and those who violate it must also be dealt with according to applicable legal procedures and provisions. POLRI as law enforcers who are tasked with maintaining order and ensuring public security, maintaining state safety and maintaining the safety of people, objects and the community, including providing protection and assistance and providing and endeavoring to comply with citizens and communities with all forms of regulations.

The main task of the investigator is: "to search for and collect evidence that with this evidence makes clear about the crime that occurred and finds the suspect" i. POLRI as investigators because of their obligations to have authority as stipulated in Article 7 paragraph (1) of the Criminal Procedure Code (KUHAP), furthermore this authority is also regulated in Article 16 paragraph (1) Act No. 2 of 2002 concerning the Republic of Indonesia Police. Indonesia.

Domestic violence is a type of violence that has distinctive characteristics, namely it is carried out in the home, the perpetrator and the victim are family members. The types of domestic violence include physical violence, psychological violence, sexual violence and neglect in the household. Therefore, everyone in the household has the potential to become both perpetrators and victims of domestic violence. In cases of domestic violence, not a few family members who commit violence are sentenced to criminal penalties, the violence committed is usually physical or psychological violence. Physical violence in question is an act that causes pain, falls ill, or is seriously injured.

The condition of very minimal attention to witness victims in all types of acts of violence and especially criminal acts of domestic violence needs attention, this is also because acts of violence so far have not been able to realize the right of protection for victims as mandated by Article 5 and Article 6 of the Law. Law of the Republic of Indonesia Number 31 of 2014 concerning Amendments to Act No. 13 of 2006 concerning Protection of Witnesses and Victims. Article 5 of the Law of the Republic of Indonesia Number 31 of 2014 concerning Amendments to Act No. 13 of 2006 concerning the Protection of Witnesses and Victims. Then Article 6 of the 
Law of the Republic of Indonesia Number 31 of 2014 concerning Amendments to Act No. 13 of 2006 concerning Protection of Witnesses and Victims.

\section{Research Methods}

The type of research used in this study is a descriptive analytical legal research type. The approach used is sociological juridical, with data collection methods in the form of literature study, document study, then interviews. The data processing technique is qualitative.

\section{Results and Discussion}

\subsection{Implementation of Domestic Violence Case Investigation}

The process of investigation, prosecution, and examination in court proceedings in cases of criminal acts of domestic violence shall be carried out according to the provisions of the applicable criminal procedural law. This has the consequence that the Criminal Procedure Code (Act No. 8 of 1891) becomes the implementation guideline in the investigation of criminal acts of domestic violence. Act No. 23 of 2004 explicitly stipulates that the victim has the right to directly report domestic violence to the local police, both at the place where the case is located and at the scene of the case (article 26). ${ }^{2}$ The victim can also authorize the family or other people to report domestic violence to the police, both at the victim's place and at the scene of the case (article 26 paragraph 2 ). In the event that the victim is a child, a report can be made by the parent, guardian, or child concerned which is carried out in accordance with the applicable legal provisions (article 27). The Head of the District Court, within a period of 7 days from the receipt of the application, he is obliged to issue a letter. a stipulation containing an order for protection for the victim and other family members, unless there is a good reason (article 28). ${ }^{3}$

Protection for victims of domestic violence is valid for a maximum of 1 year and can be extended if there is information from the victim, health worker, social worker, volunteer assistant or spiritual mentor that the victim still needs protection. There is a clear difference between the Criminal Procedure Code and Act No. 23 of 2004 in terms of the investigation process. If the Criminal Procedure Code is more concerned with the perpetrators who need to be investigated immediately, then Act No. 23 of 2004 is more concerned with providing services

\footnotetext{
${ }^{2}$ Oscar Stefanus Setjo dan Umar Ma'ruf, Investigation of Children Which Conflicting With Law in Narcotics Criminal Acts In Law Area of the Semarang City Police Jurisdiction, Jurnal Daulat Hukum Volume 3 Issue 2, June 2020, p. 287-288.

${ }^{3}$ Fransiska Natalia, Harshitha, Talita Taskiyah, Penegakan Hukum Terhadap Kekerasan Dalam Rumah Tangga Oleh Pihak Istri Di Wilayah Polres Jakarta Barat, Lex Jurnalica, Volume 17 Nomor 1, April 2020, p. 120-122.
} 
for victims to get legal protection as victims of domestic violence. ${ }^{4}$ The rights of the victims are regulated in Articles 16 to 38 of Act No. 23 of 2004. Namely: ${ }^{5}$

- Within 1 x 24 hours from knowing or receiving a report of domestic violence, the police must immediately provide temporary protection to the victim.

- This protection is provided for 7 days.

- In providing protection, the National Police can work together with health/hospital workers, social workers, volunteer assistants, spiritual guides or shelters if any.

- The Court's determination of the protection of victims by the National Police within 1x24 hours must be issued immediately.

- Applications for protection can be submitted by the victim himself or the victim's family, friends of the victim, the police, a spiritual companion or mentor. It is obligatory to immediately investigate the case after knowing or receiving a report about the occurrence of incidents of domestic violence (article 19).

Investigators have the right to make arrests and detentions in cases of domestic violence as regulated in Article 35 of the Law on the Elimination of Domestic Violence for the reasons as regulated in the Criminal Procedure Code, namely:

- So that the suspect doesn't run away

- So that the suspect does not lose evidence

- So that the suspect does not repeat the crime

- Make it easier for investigators to conduct investigative examinations.

Types or forms of violence that are psychological in nature, in its development investigators often find it difficult to ensnare the perpetrator for detention, because evidence of psychological pressure suffered by the victim must require caution in measuring the level of psychological pressure. This is where the investigator must be equipped with professional skills as an investigator or can go through an expert doctor/psychiatrist to conduct an in-depth examination of the victim. The legal rules governing acts of domestic violence are clearly regulated in Act No. 23 of 2004 but in reality, this law has not been properly and properly socialized in all levels of society, so its enforcement is very difficult, resulting in many of the investigation processes failing to stage inquiries and investigations.

\subsection{The Effectiveness of Investigation of Domestic Violence Cases in the Purwodadi Region Wilayah}

Crimes can occur anytime, anywhere and by anyone or can happen to anyone, including within the scope of the household, by people who still have close relationships, either because of blood relations, marriage, breastfeeding, parenting and guardianship, which resides in the household or other relationship is

${ }^{4}$ P. M. Hadjon, Perlindungan Hukum Bagi Rakyat Indonesia (I), PT. Bina Ilmu, Jakarta, 1987, p. 45.

${ }^{5}$ Ibnu Suka, Gunarto, and Umar Ma'ruf, Peran Dan Tanggung Jawab Polri Sebagai Penegak Hukum Dalam Melaksanaan Restorative Justice Untuk Keadilan Dan Kemanfaatan Masyarakat, Jurnal Hukum Khaira Ummah Vol. 13. No. 1. March 2018, p. 115-116. 
"personal domestic", for example because the person concerned works to help the household and resides in the household. ${ }^{6}$

The birth of Act No. 23 of 2004 concerning the Elimination of Domestic Violence, which is a milestone in Indonesia as a breakthrough by the government of the Republic of Indonesia to eliminate all forms of violence that occur in the household as a realization of the ratification of the international convention on the elimination of discrimination against women in all fields. ${ }^{7}$

The commitment of the Government of Indonesia has been stated in the dictum of Act No. 23 of 2004 as follows: ${ }^{8}$

- That every citizen has the right to feel safe and free from all forms of violence in accordance with the philosophy of Pancasila and the 1945 Constitution of the Republic of Indonesia.

- That victims of domestic violence, most of whom are women, must receive protection from the state and/or society in order to avoid and be free from violence or threats of violence, torture, or treatment that degrades the degree and dignity of humanity.

- Whereas in reality cases of domestic violence occur a lot, while the legal system in Indonesia has not guaranteed protection for victims of domestic violence. ${ }^{9}$

The purpose and objective of the issuance of this Law can be seen in Article 4 of Act No. 23 of 2004 concerning the Elimination of Domestic Violence which states, as follows:

Elimination of domestic violence aims to:

- Prevent all forms of domestic violence;

- Protect victims of domestic violence;

- Take action against perpetrators of domestic violence; and

- Maintaining the integrity of a harmonious and prosperous household.

Elimination of domestic violence is carried out based on the following principles: ${ }^{10}$

- The principle of respect for human rights;

- The principle of justice and gender equality;

- The principle of non-discrimination; and

- The principle of victim protection (see article 3 of Act No. 23 of 2004 on the elimination of domestic violence).

\footnotetext{
${ }^{6}$ Article 2 paragraphs (1) and (2) of Act No. 23 of 2004 concerning the Elimination of Domestic Violence

${ }^{7}$ Muhammad Rofik Kana, Perlindungan Hukum Terhadap Anak Yang Melakukan Tindak Pidana (Studi Kasus Di Unit Perlindungan Perempuan Dan Anak Kepolisian Resor Pati), Prosiding KONFERENSI ILMIAH MAHASISWA UNISSULA (KIMU) 2, Universitas Islam Sultan Agung Semarang, 18 October 2019, p. 39.

${ }^{8}$ Arif Septria Hendra Saputra, Gunarto, and Lathifah Hanim, Penerapan Restoratife Justice Sebagai Alternatif Penyelesaian Tindak Pidana Penganiayaan Di Satreskrim Polsek Lasem, Jurnal Daulat Hukum Vol. 1. No. 1 March 2018, p. 159.

${ }^{9}$ Act No. 23 of 2004, Introduction and Explanation

${ }^{10}$ Sarwadi and Bambang Tri Bawono, Restorative Justice Approach in Diversion System for Settlement of Criminal Cases for Children in Indonesia, Jurnal Daulat Hukum Volume 3 Issue 4, December 2020, p. 377-400.
} 
Regarding Domestic Violence, in its development there are still many families or households that do not know about acts of domestic violence, which is no longer a family matter but has become a public matter, even it is a violation of human rights and threatens human life. Besides, there are still many law enforcement officers who are not familiar with the Domestic Violence Law. So that there are obstacles for the process of investigating domestic violence cases when victims report to the RPK (Special Service Room) located at the Regional Police Sergeant in each province in Indonesia. Many investigators have not yet carried out the legal service process for victims by carrying out protective procedures specifically stipulated by Act No. 23 of 2004. This has caused victims to withdraw or withdraw their reports and complaints. The legal facilities provided by the Women and Children Protection Units at each Polres are still inadequate, for example the Integrated Service Center that provides free services to the complainant/victim has not been implemented properly. The legal awareness of citizens to comply with the Domestic Violence Law is still very minimal. Some people do not want to realize that there is a law that prohibits violence against fellow family members. Although there are community members who already know that the threat of imprisonment for perpetrators of domestic violence is still influenced by patriarchal culture or has power that goes beyond the boundaries of the family.

Related problems also occur in the Grobogan area. Since the pandemic era hit, according to the Women's Association for Justice Legal Aid Institute, there have been 110 reported cases from 2019 until the end of $2020 .{ }^{11}$ One of the cases that can be observed is the Indah case that occurred in the Keradenan area, Grobogan Regency, where in this case Indah was often the object of violence by her brother after experiencing Termination of Work in this Covid 19 Pandemic era. Indah often experienced violence in the form of plundering, beatings, and even being kicked at her master's house by her older brother Ikhsan, however, the lack of information related to law enforcement efforts and the existence of a culture of shame to be known by the wider community, Indah was initially reluctant to report. ${ }^{12} \mathrm{After}$ several approaches, the person concerned was finally willing to report to the Grobogan Police with the assistance of the Women's Association for Justice Legal Aid Institute or LBH APIK. So that the implementation of the investigation in the case of domestic violence in the Grobogan area can be said to be ineffective at this time.

\section{Closing}

The implementation of the investigation in the case of Domestic Violence in Grobogan in its development has not been said to be effective. This is because there are still many families or households who do not know that domestic violence is no longer a family matter but has become a public matter, even a violation of human rights and threatens human life. Besides, there are still many

\footnotetext{
11 https://lbhapik.or.id/, downloaded on June 12, 2021.

12 Santica Arum, Personal Interview with LBH APIK Volunteers Regarding Indah's Domestic Violence Case in KeraDenan Village, Grobogan, Interview Conducted On 12 June 2021.
} 
law enforcement officers who are not familiar with the Domestic Violence Law. So that there are obstacles for the process of investigating domestic violence cases when victims report to the RPK (Special Service Room) located at the Regional Police Sergeant in each province in Indonesia. Many investigators have not carried out the legal service process for victims by carrying out protection procedures specifically stipulated by Act No. 23 of 2004. This causes victims to withdraw or withdraw their reports and complaints. The legal facilities provided by the Women and Children Protection Units at each Polres are still inadequate. So it is necessary to have an investigation system that has adequate facilities and infrastructure and there is also a need for community involvement.

\section{References}

\section{Journal}

[1] Arif Septria Hendra Saputra, Gunarto, dan Lathifah Hanim, Penerapan Restoratife Justice Sebagai Alternatif Penyelesaian Tindak Pidana Penganiayaan Di Satreskrim Polsek Lasem, Jurnal Daulat Hukum Vol. 1. No. 1 March 2018

[2] Fransiska Natalia, Harshitha, Talita Taskiyah, Penegakan Hukum Terhadap Kekerasan Dalam Rumah Tangga Oleh Pihak Istri Di Wilayah Polres Jakarta Barat, Lex Jurnalica, Volume 17 Nomor 1, April 2020

[3] Muhammad Rofik Kana, Perlindungan Hukum Terhadap Anak Yang Melakukan Tindak Pidana (Studi Kasus Di Unit Perlindungan Perempuan Dan Anak Kepolisian Resor Pati), Prosiding KONFERENSI ILMIAH MAHASISWA UNISSULA (KIMU) 2, Universitas Islam Sultan Agung Semarang, 18 October 2019

[4] Oscar Stefanus Setjo dan Umar Ma'ruf, Investigation of Children Which Conflicting With Law in Narcotics Criminal Acts In Law Area of the Semarang City Police Jurisdiction, Jurnal Daulat Hukum Volume 3 Issue 2, June 2020

\section{Books}

[1] P. M. Hadjon, 1987, Perlindungan Hukum Bagi Rakyat Indonesia (I), PT. Bina Ilmu, Jakarta

[2] Sugiono, 2009, Metode Penelitian Kuantitatif, Kualitatif dan R\&D, Alfabeta, Bandung

\section{Regulation}

[1] 1945 Constitution of the Republic of Indonesia

[2] Criminal Code

[3] Act No. 23 of 2004 concerning the Elimination of Domestic Violence

\section{Internet}

[1] Ira Alia Maerani, https://lbhapik.or.id/, downloaded on 12 June 2021

\section{Interview}


[2] Santica Arum, Personal Interview with LBH APIK Volunteers Regarding the Case of Domestic Violence Experienced by Indah in Keradenan Village, Grobogan, Interview Conducted On 12 June 2021 